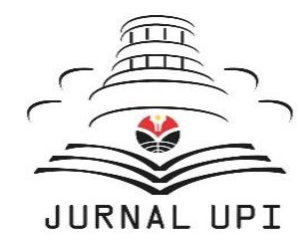

INDONESIAN JOURNAL OF APPLIED LINGUISTICS

Vol. 9 No. 3, January 2020, pp. 695-703

Available online at:

https://ejournal.upi.edu/index.php/IJAL/article/view/23220

doi: 10.17509/ijal.v 9i3.23220

\title{
Motivational teaching practices from EFL learners' perspective at tertiary level in Yemen
}

\author{
Waleed Mohammed A. Ahmed and Ali Saleh Al-Ward \\ English Department, University of Science and Technology, Sana'a, 60St. Yemen
}

\begin{abstract}
Motivation is an important factor for success in learning a foreign or second language. Creating such motivation among learners through adopting certain teaching practices is likely to stimulate learners to learn. Previous research has largely investigated motivational teaching practices from the teachers' perspective. However, little research has addressed motivational practices from the learners' perspective. In a context such as Yemen, EFL teachers at the tertiary level encounter a challenging task in creating motivational practices for learners whose preferences for teaching practices should be the cornerstone in the learning and teaching process. Therefore, this study aimed to explore whether the teaching practices adopted by teachers are motivating from the learners' perspective. To achieve this objective, a questionnaire was distributed to 137 undergraduate students in level four at the English Department within two faculties (i.e., Faculty of Education and Faculty of Languages) at Sana'a University. Data collected were analyzed using SPSS. The teaching practices which are likely to be motivating as perceived by learners were computed and compared. The findings revealed that teaching macro-practices vary in the degree of their motivation from most motivating (i.e., familiarize learners with L2 related values) to the least motivating (present tasks properly) as perceived by learners. The study also revealed that some teaching macro-practices appear to be transmitted to the Arab culture based on the learner-center approach.

Keywords: Learner-centered approach; macro-practices; motivation; teacher-centered approach; Yemeni EFL context

\begin{tabular}{|c|c|}
\hline $\begin{array}{l}\text { First Received: } \\
22 \text { June } 2019 \\
\text { Final Proof Received: } \\
7 \text { October } 2019 \\
\end{array}$ & $\begin{array}{c}\text { Accepted: } \\
\text { 30 September } 2019 \\
\text { Published: } \\
\text { 31 January 2020 }\end{array}$ \\
\hline $\begin{array}{l}\text { How to cite (in APA style): } \\
\text { Ahmed, W. M. A. \& Al-Ward, A. S. (2020). Motivational } \\
\text { perspective at tertiary level in Yemen. Indonesian Jc } \\
\text { 703. doi: } 10.17509 / \text { ijal.v9i3.23220 }\end{array}$ & $\begin{array}{l}\text { hing practices from EFL learners' } \\
\text { llof Applied Linguistics, 9, 695- }\end{array}$ \\
\hline
\end{tabular}
\end{abstract}

\section{INTRODUCTION}

Motivation has been the focus of research in second and foreign language teaching and learning over the past few decades. This may be due to the essential role of motivation for the success of language learners in all language aspects and skills (Asghar, Jamil, Iqbal, \& Yasmin, 2018; Dörnyei \& Csizér, 1998; Wilona, Ngadiman, \& Palupi, 2010). Motivated learners are more likely to achieve their goals than those demotivated ones (Vibulphol, 2016). In this regard, teachers are believed to play a key role in promoting learner's motivation by creating certain motivational practices in class (Alizadeh, 2016; Al Kaboody, 2013; Deldeniya, Khatibi, \& Asam, 2018). However, creating motivation among learners can be a challenging task for teachers (Frey \& Fisher, 2010). Teachers may adopt certain teaching practices in their classes to motivate learners. Yet, some of such practices are likely demotivating as they may not match the learners' interests (Maeng \& Lee, 2015). This makes it crucial to explore the teaching practices, which can really motivate students to learn a foreign or second language, from the learners' perspective.

A review of related literature shows that motivation is a multifaceted construct. For instance, Richards and Schmidt (2013) defined motivation as a driving force that leads to action. Similarly, Rodgers and Loitz (2009) defined it as an energy that directs one's behavior towards a certain goal. However, the most common definition of motivation in second or

\footnotetext{
* Corresponding Author

Email: w.alqadasi@ust.edu
} 
foreign language learning was given by Gardner (2010). The author defined motivation as one's central mental engine or energy that includes effort, want, or will which create task-enjoyment. This definition has been widely addressed by other scholars of second language acquisition (e.g., Dörnyei, 2010; Gardner, 2010).

Motivation is classified into two main categories: intrinsic and extrinsic. Intrinsic motivation is referred to as an internal desire or willingness to do something (Oletić \& Ilić, 2014). On the other hand, extrinsic motivation is viewed as a willingness to do something to achieve a particular goal for the sake of rewards such as scores, praise, or even getting a job (Ryan \& Deci, 2000). Intrinsic motivation can be either integrative or instrumental (Gardner, 2010). Both types of intrinsic motivation have a positive influence on learning English as a foreign language $(\mathrm{Ng} \mathrm{\&} \mathrm{Ng}, 2015)$.

Researchers have emphasized that intrinsic motivation has a greater success on second language learning than extrinsic motivation (Lucas et al., 2010). Thus, teachers need to create conducive extrinsic motivation that may enhance students' intrinsic motivation. One way of achieving this is by using motivational teaching practices (Cheng \& Dörnyei, 2007). As such, it is important for teachers to be aware of motivating practices that drive learners' intrinsic motivation to learn a foreign or second language. This may assist in creating a relaxed atmosphere in the classroom, which, in turn, may lead to raise learners' motivation and enhance their L2 performance (Ruesch, Bown, \& Dewey, 2012).

Recently, a significant number of studies have investigated learners' motivation in English language learning. Review studies have explored the role of motivation in foreign or second language learning. For instance, Al Kaboody (2013) conducted a review on the body of literature on L2 key motivation theories and the teacher's role in enhancing students' motivation to learn the language. The findings of the study revealed that teachers play a vital role in initiating learners' motivation or demotivating them towards language learning. Similarly, Alizadeh (2016) reviewed literature about the impact of motivation on second or foreign language learning. The review showed that motivation is important for the success or failure in English language learning as a foreign or second language, and teachers can play an important role in motivating learners to learn the language. The authors, i.e., Alizadeh (2016) and Al Kaboody (2013), emphasized that teachers should adopt motivational practices to stimulate learners to learn a foreign or second language. This entails the need to investigate whether teaching practices adopted in the classroom are motivating for L2 learners. The above review studies focused on the role of the teacher and the teaching practices in enhancing learners' motivation; however, the role of the learner which is a crucial component of the learning process (Dörnyei \& Chan, 2013; Richards, 2002) has not been given attention.
Some other empirical studies investigated the impact of EFL teachers' beliefs and motivational behaviors on students' learning. Muñoz and Ramirez (2015) conducted a study to identify teachers' beliefs and motivating practices in second language teaching context at a private language center in Medellin, Colombia. The findings showed that teachers' practices did not reflect teachers' beliefs about motivating practices. The study concluded that it is important to establish meaningful teacher-student relationships, which may enhance learners' motivation. This means there must be relatedness between teaching practices and learners' learning interest, which needs to be investigated. In the same vein, Maeng and Lee (2015) examined the impact of Korean in-service school EFL teachers' motivational behaviors on students' learning. The findings showed that teachers employed various strategies, such as attention-related strategies, audiovisual resources, and asking questions, to motivate students to learn. However, some of these strategies were not effective as they did not attract learners' interests or stimulate their critical thinking. This indicates that effective motivating strategies appear to be missing in the teaching practices. Moreover, the findings showed that teachers' strategies were characterized by a teacher-centered approach rather than the learner-centered approach. This has created a gap for investigating teaching practices based on the learnercentered approach that advocates the learners' interests.

Some other studies focused on teachers' and students' beliefs about teachers' use of motivational strategies and the way they use such strategies to support students' learning. For example, Alrabai (2014) explored teachers' and students' beliefs on teachers' frequency of use of motivational practices in the EFL classroom in the Saudi Arabian context. The findings indicated that teachers' beliefs of motivational practices mostly matched some aspects of learners' perceptions about motivation; however, some motivational practices were not frequently utilized in English language class es. The study entirely focused on the frequency of utilizing motivational practices by teachers. This has created a theoretical gap that Vibulphol (2016) explored by investigating the way in which teachers employ motivational strategies to support students' learning in the EFL classroom setting in Thailand. Findings indicated that most students had a fairly high level of motivation. It was noticed that teachers utilized a variety of motivational strategies such as autonomysupport strategies and controlling styles, which enhanced students' internal motivation and created an atmosphere for highly motivated performing classrooms. Teachers employed a variety of strategies to motivate learners; nevertheless, some learners remained demotivated. This is probably due to the fact that some of the teaching strategies might not match learners' interests. As such, investigating effective strategies that match learners' interests is important. Engaging learners in deciding which teaching practices match their desire 
has become crucial as it ensures greater success in language learning (Cheng \& Dörnyei, 2007).

Although students' beliefs about motivation were investigated (see Alrabai, 2014), only their opinions about the frequency of use of motivational practices in EFL classrooms were explored. The students were not given the opportunity to express their opinions on teaching practices, which can be considered motivating. Rather, the study predetermined that some teaching practices were motivating, and the students were only asked to decide the frequency of use of those teaching practices in the classroom regardless of whether the practices are motivating or demotivating. This entails conducting further studies to explore which teaching practices are motivating for learners. To achieve this, the studies should focus on the learners as an important component of the learning and teaching process rather than seeking the opinion of teachers about what is motivating for learners.

Furthermore, the study conducted by Papi and Abdollahzadeh (2011) revealed a significant relationship between teachers' motivational practice and students' motivated behavior in EFL high school classroom settings. However, these motivational practices need to be investigated in relation to learners' interests. This gap was emphasized by Alizadeh (2016) and Vibulphol (2016), who concluded that teachers could use some motivational practices to motivate learners to learn EFL, but some learners are still demotivated. Based on such conclusions, there is a need to investigate which teaching practices are motivating from the learners' perspectives so that teachers can adopt practices that can stimulate learners' attention and help them learn EFL.

In addition to the studies above, some other empirical studies, conducted in higher education context, explored various aspects of motivation such as reasons behind learners' motivation or demotivation in the learning and teaching context (e.g., Clayton \& Zusho, 2016), the level of learners' intrinsic motivation in the open and distance learning context (e.g., Firat, Kilinç, \& Yüzer, 2018), impact of learners' motivation and their identity formation while choosing their major on their academic achievement in the first year of their study (Meens, Bakx, Klimstra, \& Denissen, 2018), and commonalities and differences in forming intrinsic motivation of local and international learners in relation to their cultural background (Kazakova \& Shastina, 2019). Also, Hassan and Al-Jubari (2016) investigated students' motivation and their study engagement in an Asian context. The findings of these studies revealed that learners' intrinsic motivation is crucial for their academic achievement, and this motivation is influenced by certain factors such as personal, cognitive, contextual, sociocultural, psychological, and environmental factors. These factors should be considered for developing motivating teaching strategies (Hassan \& Al-Jubari, 2016; Kazakova \& Shastina, 2019), which can advocate learners' intrinsic motivation. Adopting teaching practices that can strengthen the connection between teachers and learners may enhance learners' motivation (Fedesco, Bonem, Wang, \& Henares, 2019).

From the review of the previous studies, it is clear that researchers have addressed motivation in relation to teachers' teaching strategies, which are based on the teacher-centered approach (Maeng \& Lee, 2015). This approach appears to be a traditional method of instruction in which the teacher can be the source of knowledge, and learners are passive recipients (Fareh, 2010). However, the shift from the teacher-centered approach to the learner-centered approach places the learners in the center of the teaching and learning process (Richards, 2002). In this approach, the learner can actively participate and engage in constructing knowledge (Baeten, Dochy, \& Struyven, 2012). Adopting the learner-centered approach can enhance learners' intrinsic motivation during the learning process (Alizadeh, 2016).

In the same line, much research has been conducted on motivational strategies in the Western contexts (e.g., Anderman \& Anderman, 2010; Dörnyei, 2006; Frey \& Fisher, 2010; Oletić \& Ilić, 2014). Yet, the findings and implications of these studies may not be valid for other cultures due to different variables such as teachers' beliefs, teaching methods, learners' background culture, and classroom learning environment (Cheng \& Dörnyei, 2007).

Moreover, as mentioned earlier, some teaching strategies adopted by teachers are motivating, whereas some others are demotivating or ineffective (Maeng \& Lee, 2015; Vibulphol, 2016). For this reason, there is a call for teachers to adopt motivational practices to motivate students to learn an EFL or ESL (Alizadeh, 2016), and for researchers to investigate teaching practices which are motivating from learners' perspective (Deldeniya et al., 2018; Vala \& Sanavi, 2015). Identifying teaching motivational practices may raise teachers' awareness of what can really contribute to the effective learning of the second language. This can assist teachers in adopting the most refined practices that match learners' interests.

It is obvious that research has hardly addressed learners' perspective of motivational teaching practices which influence their intrinsic motivation to learn the language bearing in mind that learners' viewpoints are crucial as they seem to be the cornerstone in the learning and teaching process (Dörnyei \& Chan, 2013; Richards, 2002). Therefore, it is the purpose of this study to provide insights into the role of learners in determining which teaching practices are motivating.

\section{METHOD \\ Participants \\ Participants of the study were 137 undergraduate students in level four at the English Department, Faculty of Education, and Faculty of Languages at Sana'a University. Faculty of Arts within Sana'a University, which also offers similar English programs, was}


supposed to be targeted for the population of the study. Yet, the teacher strike at the faculty made it difficult for researchers to collect data from the students. Therefore, the data were only collected from the two faculties mentioned above. The participants included all the available population. The participants are native speakers of Arabic, and they are homogenous in terms of their cultural background and education. Their ages range between 20 and 23 years. They have studied English for four years, and now they are in their final semester 2017/2018. They had adequate experience as they have been exposed to different teaching practices throughout the various stages of their study. As such, the participants were in a position to decide which teaching practices are motivating for their learning.

\section{Instrument}

The objective of this study was to investigate which teaching practices are motivating as perceived by learners. To achieve this objective, a questionnaire was used based on the empirical study done by Cheng and Dörnyei (2007). In their study, 10 most important macro teaching strategies were used for motivating learners. These include proper teacher behavior, recognize students' effort, promote learners' self-confidence, create a pleasant classroom climate, present tasks properly, increase learners' goal-orientedness, make the learning tasks stimulating, familiarize learners with L2related values, promote group cohesiveness and group norms, and promote learner autonomy. The macrostrategies adopted by Cheng and Dörnyei (2007) were meant to explore certain motivational strategies from the teachers' perspectives. However, the focus of the current study was to investigate the practices that motivate learners to learn a foreign language from the learners' perspectives. The questionnaire consists of 48 micro-practices. Some of the macro-practices were slightly modified for the sake of clarity for EFL Arab learners. In addition, the questionnaire items were translated into Arabic to ensure that the respondents understand the items fully. The items were then translated back from Arabic into English to ensure the reliability of the rendering process.

In the body of literature, the two terms 'strategies' and 'practices' have been used in research interchangeably by several scholars (e.g., Alrabai, 2014; Cheng \& Dörnyei, 2007; Muñoz \& Ramirez, 2015; Papi \& Abdollahzade, 2011; Vibulphol, 2016). Yet, the term 'practices' 'is used throughout the current study.

\section{Data analysis}

Having collected 142 questionnaires from the participants, five questionnaires were excluded as outliers. A total of 137 questionnaires were analyzed using SPSS.20. The reliability of the 48-items was obtained using Cronbach's Alpha to ensure the internal consistency of the items under each macro-practice. The findings revealed by Cronbach's Alpha were estimated to be 0.95 , which indicates that there is a high consistency between components. Then, descriptive statistics were provided to present the findings and the rank order of the macro-practices. Finally, the teaching practices which are likely to be motivating as perceived by learners were computed and compared.

\section{FINDINGS and DISCUSSIONS}

The 10 macro-teaching practices were ranked from the most to the least motivating practices based on the mean scores obtained from the participants' responses, as shown in Table 1.

Table 1. Order of motivational practices from the most motivating to the least motivating

\begin{tabular}{rlcc}
\hline \multicolumn{1}{c}{ No. } & \multicolumn{1}{c}{ Macro-practice } & Mean & SD \\
\hline 1. & Familiarize learners with L2 related value & 18.5 & 5.6 \\
2. & Promote learner autonomy & 15.9 & 4.8 \\
3. & Proper teacher behavior & 14.8 & 3.8 \\
4. & Promote group cohesiveness and group norms & 14.4 & 3.9 \\
5. & Make the learning tasks stimulating & 14 & 4.9 \\
6. & Promote learners' self-confidence & 13.7 & 3.8 \\
7. & Recognize students' efforts & 11.1 & 3.4 \\
8. & Create a pleasant classroom climate & 11 & 3.1 \\
9. & Increase learners' goal orientedness & 9.9 & 3.0 \\
10. & Present tasks properly & 5.7 & 1.9 \\
\hline
\end{tabular}

\section{Familiarize learners with $\mathrm{L} 2$ related value}

Adopting certain teaching practices such as making learners familiar with L2 background culture by engaging them in authentic activities inside and outside the classroom can promote L2-related values and make teaching materials relevant for learners (Cheng \& Dörnyei, 2007). $\mathrm{Ng}$ and $\mathrm{Ng}$ (2015) consider creating positive language-related values as a key strategy for motivating L2 learning. The findings of the current study displayed that learners placed this macro-practice in the first rank order. Although the L2 participants targeted by this study belong to a different culture, i.e.,
Arab background culture, teachers are aware of the importance of the L2 related values and thus adopted practices that aim to integrate learners in the L2 learning environment. These practices can have a highly positive impact on motivation, which means learners with positive feelings towards the second language speaking community are more successful than others in learning a second language (Gardner, 1985). In line with this, Alshehri and Etherington's (2017) study confirms that L2 teachers and learners view L2 related values crucial for second language learning. Other studies that support this finding, but from teachers' point of view, include 
Alrabai's (2014) and Kakar and Pathan's (2017) in which familiarizing learners with the L2 related values are perceived vital for motivating students to learn. However, familiarizing learners with a particular culture may take time (Kazakova \& Shastina, 2019) and as such, for successful language acquisition, teachers need to make efforts to integrate learners into the target language culture, and also share with them that English is a meaningful experience for their future career (AlMahrooqi, Abrar-Ul-Hassan, \& Cofie, 2012).

\section{Promote learner autonomy}

Learner autonomy can be defined as the learners' ability to control their own learning (Benson, 2013). Encouraging students to be self-independent learners is an important component to maintain their motivation in language learning (Cheng \& Dörnyei, 2007). The findings of the present study revealed that this macropractice adopted by teachers ranked second according to the learners' responses. This highly rated position shows that learners did not wish to be spoon-fed by their teachers, but wanted their teachers to adopt practices of autonomous nature to encourage them to become more responsible for their own learning. Thus, if learners were given chances to be autonomous, they would definitely develop intrinsic motivation and take responsibility for their learning. Such an autonomous learning climate can positively contribute to their active engagement in learning tasks (Hassan \& Al-Jubari, 2016). Fareh (2010) argued that learning L2 in the Arab World is governed by the teacher-centered approach. However, affected by the shift of focus in the L2 learning process from the teacher-centered to learnercentered approach in Western countries (Richards, 2002), the learners in the present study acknowledged that teachers were facilitators in the learning process. Facilitating students' learning by engaging them in individual and group activities, giving them the opportunity to participate in evaluating themselves and raising their awareness about the importance of language learning can play a key role in developing their intrinsic motivation which can lead them to be self-autonomous (Cheng \& Dörnyei, 2007; Ryan \& Deci, 2000). For promoting learners' autonomy, teachers should take into account that learners are responsible for the learning process and participate in setting the objectives of the course, choosing the contents of materials, deciding learning strategies, and evaluating their learning. Therefore, teachers should adopt the role of a facilitator, which has been proved effective in enhancing students' learning skills, particularly problem-solving (Koehler, Ertmer, \& Newby, 2018). Also, giving learners an opportunity to self-assess their performance can provide unique feedback that may help to develop a deeper level of selfreflection and contribute to their positive changes (Snead \& Freiberg, 2019).

\section{Proper teacher behavior}

Proper teacher behavior is among the most significant macro-teaching practices and ranked third, as revealed by learners. Learners believed that their teacher behavior had a direct impact on their performance. This implies that teachers behave more positively towards learners. Previous research placed a substantial role in teacher behavior to create a conducive learning climate in the classroom and, thus, increase students' learning desire (Freeman, Anderman, \& Jensen, 2007). Appropriate teacher behavior in the learning and teaching process can stimulate students' desire to learn, particularly when the teacher projects enthusiasm in teaching and cares for students (Cheng \& Dörnyei, 2007). This can be achieved by answering students' questions, clearing their doubts, helping them to overcome their learning problems (Ball \& Forzani, 2009), generating their autonomy and competence and even raising their awareness about the importance of English for their future (Noels, Pelletier, Clément, \& Vallerand, 2000). In addition, teachers can provide a role model, engage learners in various cooperative learning activities, and show care for their learning progress. For effective teachers' proper role, relatedness with learners can break barriers and formalities between teachers and learners, which may enhance learners' intrinsic motivation and stimulate them to learn the language (Fedesco et al., 2019).

\section{Promote group cohesiveness and group norms}

Group cohesion and group norms have been viewed as key factors that have considerable influence on team performance (Carless \& De Paolo, 2000). The findings of this study revealed that group cohesion and group norms ranked fourth according to the participants. It can be assumed that the effect of this macro-practice, as perceived by learners, may lead to an increase in learners' intrinsic motivation and interpersonal experiences. Teaching practices that consider involving students in setting class rules and sharing their personal experiences can motivate them to learn from each other and work collaboratively to achieve the goal of the course (Cheng \& Dörnyei, 2007). Creating cohesiveness in the class requires setting certain norms by the teachers. These norms include instructions that should be introduced at an early stage of the group. Furthermore, teachers have to be tolerant of students' mistakes and errors ( $\mathrm{Ng} \& \mathrm{Ng}, 2015)$. Teachers are considered the source of learners' motivation, which can positively influence and reinforce their learning, particularly when those teachers are self-motivated (Frenzel, Taxer, Schwab, \& Kuhbandner, 2019).

\section{Making the learning tasks stimulating}

This macro-practice was ranked fifth according to the participants' responses. The ranking of this macropractice in the current study appears to be closer to Dörnyei and Csizér's (1998) study, which investigated teaching macro-practices, but from the teachers' perspective. Therefore, teachers can stimulate learners by presenting interesting topics in class, using various teaching aids, and engaging learners in various challenging learning tasks (Cheng \& Dörnyei, 2007). In the context of the present study, it is quite obvious that 
teaching in an Arab setting such as Yemen seems to follow what is called 'teacher-centered approach' (Asaad, 2019; Fareh, 2010) in which learners are not engaged in determining their preferred learning topics and style. In addition, teachers' goal is to transfer knowledge and experiences to learners for the purpose of getting them to pass examinations. Learners, therefore, believe that teaching English in the classroom lacks interesting tasks, which, in turn, may lead to getting learners away from engagement in the learning process. As Park (2003) argued, students who actively engage with what they are studying are likely to understand more than those who passively receive what they are taught.

\section{Promote learners' self-confidence}

Self-confidence is a state of positive feeling that exists in every person since his/ her childhood (Mutluer, 2006). Promoting learners' self-confidence ranked sixth according to the responses of participants. This means teachers who enhance learners' confidence can create a scaffolding for more effective and efficient learning. According to Life (2011), self-confidence is one of the key factors in second language learning, which can be a premise for motivation. Teachers' awareness of the importance of learners' self-confidence can help in triggering learners' intrinsic motivation to learn the language. Promoting such confidence can be achieved through certain factors. These include developing learners' learning strategies, engaging them in appropriate but challenging tasks that focus on communicating meaning, and providing them with positive feedback about their performance (Cheng \& Dörnyei, 2007). This definitely can lead to getting learners to improve their own learning without relying much on their own teachers.

\section{Recognize students' efforts}

It has been well documented that the efforts teachers exert in teaching are likely to have a strong impact on the learners' motivation (Stipek, 2002). The macropractice 'recognize students' efforts' was ranked seventh according to the participants, which indicates that teachers did not seem to consider it important. The reason why this macro-practice is underutilized lies probably in the fact that students did not feel much that their teachers exerted themselves much in how to recognize students' success. Another reason could be due to the socio-economic factor that teachers encounter in Yemen. Teachers at public universities have not been rewarded by the respective universities, which created low motivation for their teaching practices. To motivate students to learn, teachers need to recognize their efforts by monitoring and praising their learning process (Cheng \& Dörnyei, 2007). This practice will, of course, boost learners' efforts to become competent in language learning (Al Othman \& Shuqair, 2013). It is worth mentioning that the same macro-practice in Dörnyei and Csizér's (1998) study perceived from teachers' perspective was not placed among the highest rated practices.

\section{Create a pleasant class room climate}

Pleasant climate can be created through interesting opening activities, risk-taking tasks, and humor (Cheng \& Dörnyei, 2007), which help in creating a positive learning atmosphere that enhances students' academic performance (Brown, Jones, LaRusso, \& Aber, 2010). However, the findings of the current study placed creating a pleas ant and inclusive classroom climate in a low position, i.e., eighth. The finding obtained is dissimilar to Cheng and Dörnyei's (2007) study in which this macro-practice was in the top position. Such dissimilarity may be attributed to the culture-specific setting, i.e., the Yemeni context in which the learning environment is dominated by unstable political and economic conditions. Therefore, Yemeni learners have placed this macro-practice in the low ranking due to certain constraints, one of which is the civil-military conflict, which brought about an insecure learning environment. Since 2015, dozens of schools and universities were partially or completely damaged throughout the armed conflict. This situation had a harsh impact on the learning environment, in general, and learners' academic performance, in particular.

\section{Increase learners' goal-orientedness}

As the concept of goal-orientedness focusses on the extent to which the learners are aware of the intended learning outcomes (Dörnyei \& Ushioda, 2011), setting a clear goal for L2 learners can surely facilitate their learning (Chen, Wang, \& Chen, 2014) and generate their initial motivation $(\mathrm{Ng} \& \mathrm{Ng}, 2015)$. Engaging learners in the goal-setting process will help to increase their interest (Pintrich, 2000), which may have a positive impact on their performance (Moeller, Theiler, $\& \mathrm{Wu}, 2012)$. However, the findings of the current study placed the learners' goal-oriendtedness in the ninth rank, which is in congruence with findings of the study conducted by Dörnyei and Csizér's (1998). The low position of this macro-practice can be attributed to the nature of the teaching practices characterized by the teacher-centered approach, which is still a common practice among Arab teachers (Fareh, 2010). Teachercenteredness seems to be dominating in both schools and universities alike, more specifically in terms of learners' disengagement in the goal-setting process. Distancing learners from being engaged in the goalsetting process might create a wide gap between learners and the intended learning outcome. This implies that policymakers and curriculum designers need to consider the involvement of learners in the goalsetting process, which can positively contribute to motivating learners and enhancing their performance level.

\section{Present tasks properly}

Presenting tasks properly requires that various teaching activities should be interesting and challenging to maintain learners' motivation (Anderman \& Anderman, 2010; Cheng \& Dörnyei, 2007). However, the findings of the current study placed this macro-practice as the 
most underutilized according to the participants' responses, i.e., tenth, which is in congruence with the findings of the study conducted by Cheng and Dörnyei (2007). This could be due to the fact that the political unrest and the wobbly economic conditions which stormed the whole country, i.e., Yemen, have created a negative impact on teachers' performance. As such, this probably justifies why this macro-practice was not given attention by teachers. This might have led learners to expect minimal teaching practices from the teachers' side. As Siyum and Gebremedhin (2015) report, to teach effectively, teachers need to carry out responsibility transparently and be free from any political burdens. In the case of the current study, teachers have been thinking more about themselves than their students' needs. This situation definitely had a negative impact on the teachers' performance, which might have resulted in an ineffective learning process at the university context.

\section{CONCLUSION}

The current study aimed to explore whether the teaching practices adopted by teachers in the EFL classroom are motivating from the learners' perspectives. On the basis of the learner-centered approach, the study attempted to draw insights into the teaching practices at the tertiary level in Yemen. As perceived by learners, teaching macro-practices vary in the degree of their motivation from most motivating (i.e., familiarize learners with L2 related values) to the least motivating (present tasks properly). Based on such findings, the authors drew certain conclusions. Learners' preferences for the most macro-teaching practices were obviously derived from the learner-centered approach, which indicates that some of the teaching practices highly emphasize the implementation of the learner-centered approach. This shows teachers' tendency towards developing selfdriven learners, although the teachers belong to the Arab cultural context, i.e., Yemen, which advocates the teacher-centered approach in both schools and universities.

It is also evident that learners' awareness of teachers' proper behavior and promoting group cohesiveness and norms is one of the sources that can greatly stimulate their intrinsic motivation. The concept of group cohesiveness is probably derived from the Arab culture in which 'role models' and 'sense of belonging' are highly valued. Another source of motivation is the teacher's role in assisting learners in developing self-confidence and stimulating them to share experiences and construct new knowledge. Learners' engagement in setting learning outcomes of the course seems to be neglected, which means learners do not have a substantial role in choosing their preferred learning tasks. This implies that learners are distanced from being involved in the goal-setting process. Furthermore, the current unstable socio-economic conditions which have stormed the country (i.e., Yemen) have brought about negative consequences over teachers' practices in terms of recognizing learners' efforts and creating a pleasant classroom climate. The learning environment has not been conducive owing to the armed conflict, which has left negative consequences over learners' academic performance.

This study provides learners' perceptions of teaching practices in the tertiary classroom setting. However, the actual teaching practices need to be investigated in context through classroom observation. A more comprehensive study can investigate the aspects of the dominated approach adopted in the classroom (i.e., teacher-centered or learner-centered).

\section{REFERENCES}

Al Kaboody, M. (2013). Second language motivation: The role of teachers in learners' motivation. Journal of Academic and Applied Studies, 3(4), 45-54.

Al Othman, F. H., \& Shuqair, K. M. (2013). The impact of motivation on English language learning in the Gulf States. International Journal of Higher Education, 2(4), 123-130. doi: 10.5430/ijhe.v 2n4p123

Alizadeh, M. (2016). The impact of motivation on English language learning. International Journal of Research in English Education, 1(1), 11-15.

Al-Mahrooqi, R., Abrar-Ul-Hassan, S., \& Cofie, C. (2012). Analyzing the use of motivational strategies by EFL teachers in Oman. Malaysian Journal of ELT Research, 8(1), 36-76.

Alrabai, F. (2014). Motivational practices in English as a foreign language classes in Saudi Arabia: Teachers beliefs and learners perceptions. Arab World English Journal, 5(1), 224-246.

Alshehri, E., \& Etherington, M. S. (2017). Motivational strategies: The perceptions of EFL teachers and students in the Saudi higher education context. International Journal of English Language Education, 5(2), 46-82. doi: 10.5296/ijele.v 5i2.11727

Anderman, E. M., \& Anderman, L. H. (2010). Classroom motivation. Upper Saddle River, New Jersey: Merrill.

Asaad,H. Q. M. (2019). Idea sharing: Analyzing the principles and techniques of English language teaching emphasized in the Crescent English Course for Yemen. PASAA Journal of Language Teaching and Learning, 57, 191-208.

Asghar, A., Jamil, I., Iqbal, A., \& Yasmin, M. (2018). Learner attitude towards EFL learning: A response from art and design. Open Journal of Social Sciences, 6(05), 81-88. doi: $10.4236 /$ js s.2018.65007

Baeten, M., Dochy, F., \& Struyven, K. (2012). Using students' motivational and learning profiles in investigating their perceptions and achievement in case-based and lecture-based learning environments. Educational Studies, 38(5), 491506. doi: 10.1080/03055698.2011.643113. 
Benson, P. (2013). Teaching and researching: Autonomy in language learning. Routledge.

Brown, J., Jones, S., LaRusso, M., \& Aber, J. (2010). Improving classroom quality: Teacher influences and experimental impacts of the 4Rs program. Journal of Educational Psychology, 102 (1), 153167. doi: $10.1037 / \mathrm{a} 0018160$

Carless, S. A., \& De Paola, C. (2000). The measurement of cohesion in work teams. Small group research, 31(1), 71-88. doi: 10.1177/104649640003100104

Chen, C. M., Wang, J. Y., \& Chen, Y. C. (2014). Facilitating English-language reading performance by a digital reading annotation systemwith self-regulated learning mechanisms. Journal of Educational Technology \& Society, 17(1), 102-114.

Cheng, H. F., \& Dörnyei, Z. (2007). The use of motivational strategies in language instruction: The case of EFL teaching in Taiwan. International Journal of Innovation in Language Learning and Teaching , 1(1), 153-174. doi: doi.org/10.2167/illt048.0

Clayton, K. E., \& Zusho, A. (2016). A cultural heuristic approach to the study of Jamaican undergraduate students' achievement motivation. British Journal of Educational Psychology, 86(1), 8-36. doi: 10.1111/bjep.12081

Deldeniya, V. M., Khatibi, A., \& Asam, S. F. (2018). Preferences for motivational strategies: A comparis on of student and teacher perspective in Japanese as a foreign language (JFL) classroom in Sri Lanka. European Journal of Education Studies, 5(2), 118-132. doi: 10.5281/zenodo. 1421077

Dörnyei, Z. (2006). Individual differences in second language acquisition. AILA review, 19(1), 42-68. doi: 10.1075/aila.19.05dor

Dörnyei, Z. (2010). Researching motivation: From integrativeness to the ideal L2 self. Introducing applied linguistics: Concepts and skills, 3(5), 7483.

Dörnyei, Z., \& Chan, L. (2013). Motivation and vision: An analysis of future L2 self-images, sensory styles, and imagery capacity across two target languages. Language Learning, 63(3), 437-462. doi: 10.1111/lang.12005

Dörnyei, Z., \& Csizér, K. (1998). Ten commandments for motivating language learners: Results of an empirical study. Language teaching research, 2(3), 203-229. doi: $10.1191 / 136216898668159830$

Dörnyei, Z., \& Ushioda, E. (2011). Teaching and researching: Motivation ( $2^{\text {nd }}$ Edn.). Harlow: Longman Pearson.

Fareh, S. (2010). Challenges of teaching English in the Arab world: Why can't EFL programs deliver as expected? Procedia-Social and Behavioral Sciences, 2(2), 3600-3604. doi: 10.1016/j.s bs pro.2010.03.559
Fedesco,H. N., Bonem, E. M., Wang, C., \& Henares, R. (2019). Connections in the classroom: Separating the effects of instructor and peer relatedness in the basic needs satisfaction scale. Motivation and Emotion, 43(5), 758-770. doi: 10.1007/s 11031 019-09765-x.

Firat, M., Kilinç, H., \& Yüzer, T. V. (2018). Level of intrinsic motivation of distance education students in e-learning environments. Journal of Computer Assisted Learning, 34(1), 63-70. doi: 10.1111/jcal.12214

Freeman, T. M., Anderman, L. H., \& Jensen, J. M. (2007). Sense of belonging in college freshmen at the classroom and campus levels. The Journal of Experimental Education, 75(3), 203-220. doi: 10.3200/JEXE.75.3.203-220

Frenzel, A. C., Taxer, J. L., Schwab, C., \& Kuhbandner, C. (2019). Independent and joint effects of teacher enthusiasmand motivation on student motivation and experiences: A field experiment. Motivation and Emotion, 43(2), 255265. doi: 10.1007/s 11031-018-9738-7

Frey, N., \& Fisher, D. (2010). Motivation requires a meaningful task. English Journal, 30-36. doi: 10.2307/20787688

Gardner, R. C. (1985). Social psychology and second language learning: The role of attitudes and motivation. London: Edward Arnold.

Gardner, R. C. (2010). Motivation and second language acquisition: The socio-educational model (Vol. 10). New York: Peter Lang.

Hassan, A., \& Al-Jubari, I. (2016). Motivation and study engagement: A study of Mus lim undergraduates in Malaysia. Pertanika Journal of Social Sciences \& Humanities, 24(3), 937951.

Kakar, S. K., \& Pathan, Z. H. (2017). Exploring the motivational strategies practiced by Pakistani EFL teachers to motivate students in learning English language. International Journal of English Linguistics, 7(2), 117-123. doi: 10.5539/ijel.v7n2p117

Kazakova, J. K., \& Shastina, E. M. (2019). The impact of socio-cultural differences on formation of intrinsic motivation: The case of local and foreign students. Learning and Motivation, 65, 19. doi: 10.1016/j.lmot.2018.10.001

Koehler, A. A., Ertmer, P. A., \& Newby, T. J. (2018). Developing preservice teachers' instructional design skills through case-based instruction: Examining the impact of discussion format. Journal of Teacher Education, 70(4), 319-334. doi: 10.1177/0022487118755701

Life, J. (2011). Motivation and EFL university students in North-East Asia. Asian EFL Journal, 13(3), 11-41.

Ball, D. L., \& Forzani, F. M. (2009). The work of teaching and the challenge for teacher education. Journal of Teacher Education, 60(5), 497-511. doi: $10.1177 / 0022487109348479$ 
Lucas, R. I., Pulido, D., Miraflores, E., Ignacio, A., Tacay, M., \& Lao, J. (2010). A study on the intrinsic motivation factors in second language learning among selected freshman students. Philippine ESL Journal, 4(1), 3-23.

Maeng, U., \& Lee, S. M. (2015). EFL teachers'behavior of using motivational strategies: The case of teaching in the Korean context. Teaching and Teacher Education, 46, 25-36.

Meens, E. E., Bakx, A. W., Klimstra, T. A., \& Denissen, J. J. (2018). The as sociation of identity and motivation with students' academic achievement in higher education. Learning and Individual Differences, 64, 54-70. doi: 10.1016/j.lindif.2018.04.006

Moeller, A. J., Theiler, J. M., \& Wu, C. (2012). Goal setting and student achievement: A longitudinal study. The Modern Language Journal, 96(2), 153-169.

Muñoz, A., \& Ramirez, M. (2015). Teachers' conceptions of motivation and motivating practices in second-language learning: A selfdetermination theory perspective. Theory and Research in Education, 13(2), 198-220. doi: $10.1177 / 1477878515593885$

Mutluer, S. (2006). The role of moral values in forming self-confidence (Unpublished doctoral dissertation). Ankara University, Ankara, Turkey.

Ng, C. F., \& Ng, P. K. (2015). A review of intrinsic and extrinsic motivations of ESL learners. International Journal of Languages, Literature and Linguistics, 1(2), 98-105. doi: 10.7763/IJLLL. 2015.V1.20

Noels, K. A., Pelletier, L. G., Clément, R., \& Vallerand, R. J. (2000). Why are you learning a second language? Motivational orientations and selfdetermination theory. Language learning, 50(1), 57-85. doi: 10.1111/0023-8333.00111

Oletić, A., \& Ilić, N. (2014). Intrinsic and extrinsic motivation for learning English as a foreign language. ELTA Journal, 2(2), 23-38.

Papi, M., \& Abdollahzadeh, E. (2011). Teacher motivational practice, student motivation, and possible L2 selves: An examination in the Iranian EFL context. Language Learning, 62(2), 571-594. doi: 10.1111/j.1467-9922.2011.00632.x

Park, C. (2003). Engaging students in the learning process: The learning journal. Journal of Geography in Higher Education, 27(2), 183-199. doi: 10.1080/0309826032000107496

Pintrich, P. R. (2000). Multiple goals, multiple pathways: The role of goal orientation in learning and achievement. Journal of Educational Psychology, 92(3), 544-555. doi: 10.1037/0022-0663.92.3.544

Richards, J. C. (2002). 30 years of TEFLTESL: A personal reflection. RELC Journal, 33(2), 1-35. doi: 10.1177/003368820203300201

Richards, J. C., \& Schmidt, R. W. (2013). Longman dictionary of language teaching and applied linguistics. Routledge.

Rodgers, W. M., \& Loitz, C. C. (2009). The role of motivation in behavior change: How do we encourage our clients to be active? ACSM's Health \& Fitness Journal, 13(1), 7-12.

Ruesch, A., Bown, J., \& Dewey, D. P. (2012). Student and teacher perceptions of motivational strategies in the foreign language classroom. Innovation in Language Learning and Teaching, 6(1), 15-27. doi: $10.1080 / 17501229.2011 .562510$

Ryan, R. M., \& Deci, E. L. (2000). Intrinsic and extrinsic motivations: Classic definitions and new directions. Contemporary Educational Psychology, 25(1), 54-67. doi: 10.1006/ceps.1999.1020

Siyum, B. A., \& Gebremedhin, M. A. (2015). Teachers in politics: Impact of political party membership on teachers' freedom and stability. The case of Nigste-Saba High School, Adwa, Tigray, Ethiopia. Journal of Education and Practice, 6(13), 223-235.

Snead, L. O., \& Freiberg, H. J. (2019). Rethinking student teacher feedback: Using a selfassessment resource with student teachers. Journal of Teacher Education, 70(2), 155-168. doi: 10.1177/0022487117734535

Stipek, D. (2002). Good instruction is motivating. In A Wigfield \& J. S. Eccles (Eds.), Development of achievement motivation (pp. 309-332). San Diego: Academic Press.

Vala, N. G., \& Sanavi, R. V. (2015). Analyzing the use of motivational strategies among Iranian inservice EFL teachers. Journal of Educational and Management Studies 5(1), 80-84.

Vibulphol, J. (2016). Students' motivation and learning and teachers' motivational strategies in English classrooms in Thailand. English Language Teaching, 9(4), 64-75. doi: 10.5539/elt.v9n4p 64

Wilona, A., Ngadiman, A., \& Palupi, M. R. (2010). The correlation between intrinsic motivation and speaking proficiency of the English department students. Magister Scientiae, 27, 45-56. 